\title{
ESTIMATING THE INEQUALITY OF LEGAL AND LATENT INCOMES WITH REGARD TO THE PURCHASING POWER OF ROUBLE IN THE RUSSIAN REGIONS ${ }^{1}$
}

The paper presents the research results of monetary income differentiation of the population with use of the author's methodical approach with regard to different purchasing power of ruble in the Russian regions. All the population of Russia was rearranged from regional quintile groups into the all-Russian groups that resulted

1 The research is completed with financial support from the Russian Humanitarian Research Foundation (RHRF) within the framework of the scientific RHRF project «Income differentiation of the population and the state policy aimed at reduction of the given phenomenon in the Russian Federation», project № 09-02-00009a. in significant changes of inequality parameters at the interregional level of incomes in comparison with the Rosstat parameters. For the first time an influence of latent incomes to inequality and poverty level in the Russian regions is analyzed. Division of the population of the country into needy and wealthy groups is offered. Calculations and recommendations regarding redistributive overcoming of poverty at the expense of increase of the rate of surtax on incomes of the wealthy group are developed. The models by Pen, Lorenz and Ravallion-Huppi, modified by the authors of the article, 
were applied in the research. Calculations were carried out for all subjects of the Russian Federation (without the Chechen republic) according to the Russian State Statistics Service figures for 2000-2008.

Numerous publications of social and economic orientation pay much attention to differentiation of the population's incomes and poverty. The Ural scientists write in a collective research: «For the last twenty years at the time of the ideological, political, economic, legal and social transformations of Russia the living conditions of the Russian society have radically changed. Separation of duties of federal, regional and municipal levels of power, growth of political and economic independence of constituent territories of the Russian Federation strengthened differentiation of the economic and social situation of regions of the country and, consequently the incomes of various population groups, working conditions and rest, degree of social security and so forth ... along with the territories with a low standard of living and population's incomes there are the territories with high level of incomes of population, close to the level of developed states» [6, p.1010, 1037]. Deep inequality of incomes, and consequently social possibilities of citizens expressing in inequality of education affordability, improvement of professional skills and so on, hamper development of the innovative economy, and, finally, progress of the society. Constant monitoring of social indicators that adequately reflects the situation in regions, and efficient taking of political measures on the basis of such a monitoring, is, from our point of view, one of the major problems of the government. At present, according to the market economy laws, apart from deep differentiation of nominal monetary incomes of the population, deep differentiation of prices for goods and services in the regions of the Russian Federations is observed, and it considerably influences standards of living in the regions. However, official statistics does not consider the regional difference in terms of the ruble purchasing power in the regions of the Russian Federation.

The purpose of the present research is monetary income and poverty level differentiation assessment by means of the technique developed by the authors considering parity of ruble purchasing power in the regions of Russia. A matter of influence of latent incomes on change of inequality and poverty level of the population was of particular interest for the researchers.

In this connection we will designate the content of terms used in the research.
Monetary incomes of population include incomes derived from business, paid salary of hired workers (charged wage corrected on the change of delayed debts), social payments (pensions, grants, insurance compensation and other payments), incomes derived from property in the form of interest on deposits, securities, dividends and other incomes («latent» incomes, incomes derived from foreign currency sale, remittances, as well as incomes which do not have wide expansion).

Latent incomes are latent payments, latent incomes derived from business and informal activity.

Legal incomes are subtraction of the sum of monetary incomes and latent incomes of the population.

The parity of purchasing power of ruble (PPPR) in a region is calculated as a ratio between an average Russian cost of a fixed set of goods and services and the cost of the given set in a given region (in average annual prices).

The results of the research for 2000-2008 are presented in the article. The given technique was first used by the authors when doing an analysis of regional differentiation of monetary incomes of the population for 2000-2006 [5]. In 2009 the authors analyzed the influence of in-kind social transfers on the level of income differentiation of the population [4]. The question of necessity of account for latent incomes was brought up by the authors in 2008 [3].

The Russian State Statistics Service figures for 2000-2008 were used as an information base for the present study. Calculations were carried out for all constituent territories of the Russian Federation (apart from the Chechen Republic) and five 20-percent (quintile) population groups in each constituent territory.

At the initial stage of the investigation average monthly per capita income of the quintile population group in average Russian basic year prices was calculated. The last year of an analyzed period is the basic year in the method. For this purpose monetary incomes were first converted into basic year prices with the help of regional deflator indexes and then multiplied by the parity of purchasing power of ruble (PPPR) to the Russian average in a given region in 2008. An average annual living wage and latent incomes were similarly recalculated in average Russian 2008 prices. This ensured comparability of parameters in the money terms in time and for different regions. Regional deflator indices of the population's monetary income were used as deflators for income and living wage. The PPPR was calculated as a ratio between an average Russian cost of a fixed set of goods and services and the 
cost of this set in a given region (in average annual prices). The «cost of a fixed set of consumer goods and services» parameter has been calculated by the Federal State Statistics Service since the end of 2000 and is specially intended for interregional comparison of the population's purchasing capacity in particular regions of the Russian Federation. High interregional differentiation in prices causes the need to take into account the ruble purchasing power when making inter-regional comparison between income levels. The choice of the initial period of the research is stipulated right by it.

In 2008 the PPPR levels in the regions of the Russian Federation varied from 0.598 in the Kamchatka region to 1.254 in the Republic of North Ossetia. The PPPR was almost equal to the value of the Leningrad region -0.999 . This signifies in essence that purchasing power of the average Russian ruble amounted to 59.8 kopecks in Kamchatka, 1 ruble and 25.4 kopecks in the Republic of North Ossetia, almost 1 ruble in the Leningrad region.

At the second stage of calculations the analyzed population groups were ranged in order of increase in average per capita incomes, then the Gini coefficient, fund coefficients and other parameters that were necessary for the regional and All-Russian analysis were calculated.

The calculation of the Gini coefficient performed at the first two stages showed greater depth of inequality than the estimates published by the Rosstat in the analyzed period. The period of 2008 was an exception, as it was the beginning of the financial and economic crisis (figure 1).

The analysis showed that such serious divergences are caused by the fact that when regional population groups are ranged according to the increase in average per capita incomes, many of them move from the initial quintile groups to other groups. Thus, the $4^{\text {th }}$ quintile group of the Moscow and Tyumen region fall to the $5^{\text {th }}$ quintile group of the Russian population, the $2^{\text {nd }}, 3^{\text {rd }}$ and $4^{\text {th }}$ quintile population

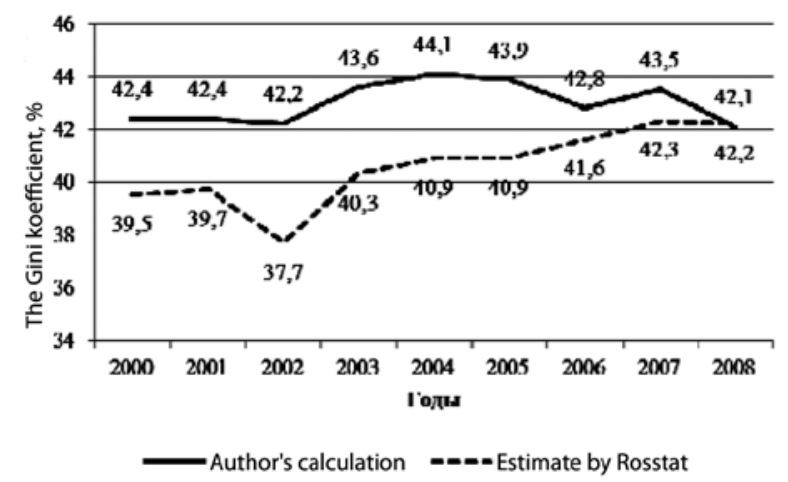

Fig. 1. The Gini coefficient for the Russian population groups in 2000-2008. (\%; average Russian prices of 2008) groups in Ingushetia, Kalmykia, Tyva, Adygea appear in the first group of the Russian Federation. The most considerable number of movements are in the $2^{\text {nd }}, 3^{\text {rd }}$ and $4^{\text {th }}$ Russian groups. For example, the $2^{\text {nd }}$ Russian quintile group includes the $3^{\text {rd }}$ and $4^{\text {th }}$ groups of Ingushetia and Kalmykia. Thus, we think, it is necessary to distinguish regional quintile population groups and Russian quintile groups. The regional groups are formed according to the levels of the population's incomes in regions, and the Russian groups are formed according to the levels of the population's incomes in all the country.

In 2000-2008 the following trends were generally observed:

- the higher the level of income, the deeper the inequality inside the group: in 2008 in the Russian Federation the coefficient was in the $1^{\text {st }}$ quintile group $-7 \%$, in the $2^{\text {nd }}-8.6 \%$, in the $3^{\text {rd }}-10.4 \%$, in the $4^{\text {th }}-12.9 \%$, in the $5^{\text {th }}-18.3 \%$;

- reduction in inequality inside the group was in all the quintile population groups. In the analyzed period the Gini coefficient in the $1^{\text {st }}$ (the poorest) group decreased by 5.4 percentage points (p.p.); in the $2^{\text {nd }}-4.4$ p.p.; in the $3^{\text {rd }}-4.5$ p.p.; in the $4^{\text {th }}-6.9$ p.p.; in the $5^{\text {th }}-12.3$ p.p. Thus, the most significant decrease in inequality was in the quintile group of the richest population in the analyzed period;

- the greater the level of the population's incomes, the higher the rate of their growth (the Central Federal District was an exception. The incomes of the $5^{\text {th }}$ group increased 2.45 times as much, which is minimum growth among all five quintile groups in the analyzed period, and the maximum growth was in the $3^{\text {rd }}$ group -2.93 times as much. In 2000-2008 over the Russian Federation average per capita monetary incomes (in 2008 prices) increased 2.72 times as much, the incomes of the $1^{\text {st }}$ quintile group -2.28 times, the $2^{\text {nd }}-2.5$ times, the $3^{\text {rd }}-2.65$ times, the $4^{\text {th }}-2.76$ times, the $5^{\text {th }}-2.83$ times as much. In 2008 smoothing of the difference in increase took place, i. e. incomes over the Russian Federation between 2007 and 2008 increased 1.2 times as much, and in the $1^{\text {st }}$ group 1.22 times, in the $5^{\text {th }}-1.19$ times.

The calculated average per capita income with regard to the PPPR over the Russian Federation is less than the average per capita income published by Rosstat. For example, in 2008 the average per capita monetary income (AMI) with the regard to the PPPR over the Russian Federation as a whole amounted to 14491 rubles, without the PPPR - 14932.2 rubles. Growth of average per capita incomes in federal districts was uneven (Table 1). 
Table 1

Average per capita monetary incomes of the population in Federal Districts (in Russian average 2008 prices)

\begin{tabular}{|c|c|c|c|c|c|}
\hline \multirow[b]{2}{*}{ Federal district } & \multicolumn{2}{|c|}{$\begin{array}{c}\text { AMI with } \\
\text { PPPR in } 2008 \\
\text { prices (ruble) }\end{array}$} & \multirow[b]{2}{*}{$\begin{array}{l}\text { Growth } \\
\text { coefficient } \\
\text { (times) }\end{array}$} & \multicolumn{2}{|c|}{$\begin{array}{c}\text { Rating of } \\
\text { AMI }\end{array}$} \\
\hline & 2000 & 2008 & & 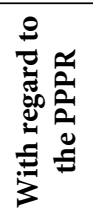 & 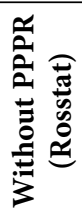 \\
\hline Central District & 6349 & 16700 & 2.63 & 2 & 1 \\
\hline $\begin{array}{l}\text { North-Western } \\
\text { District }\end{array}$ & 5494 & 14070 & 2.56 & 3 & 4 \\
\hline $\begin{array}{l}\text { Southern } \\
\text { District }\end{array}$ & 3922 & 11858 & 3.02 & 7 & 7 \\
\hline Volga District & 4862 & 13680 & 2.81 & 4 & 6 \\
\hline Ural District & 6329 & 17896 & 2.83 & 1 & 2 \\
\hline $\begin{array}{l}\text { Siberian } \\
\text { District }\end{array}$ & 5055 & 13464 & 2.66 & 5 & 5 \\
\hline $\begin{array}{l}\text { Far-Eastern } \\
\text { District }\end{array}$ & 4848 & 11919 & 2.46 & 6 & 3 \\
\hline $\begin{array}{l}\text { Russian } \\
\text { Federation }\end{array}$ & 5327 & 14491 & 2.72 & & \\
\hline
\end{tabular}

Table 2

Indices of an inequality level of average per capita monetary incomes in the constituent territories of Russia in 2008 (in Russian average 2008 prices)

\begin{tabular}{|c|c|c|c|c|}
\hline $\begin{array}{l}\text { Federal } \\
\text { district }\end{array}$ & \multicolumn{2}{|c|}{$\begin{array}{l}\text { Minimum and maximum } \\
\text { monetary income, rubles }\end{array}$} & 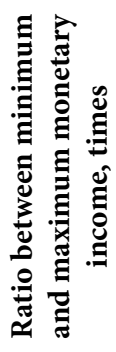 & 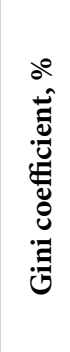 \\
\hline \multirow{2}{*}{$\begin{array}{l}\text { Central } \\
\text { District }\end{array}$} & Voronezh region & 2924 & \multirow{2}{*}{23.9} & \multirow{2}{*}{45.6} \\
\hline & Moscow city & 69900 & & \\
\hline \multirow{2}{*}{$\begin{array}{l}\text { North- } \\
\text { Western } \\
\text { District }\end{array}$} & Novgorod region & 3474 & \multirow{2}{*}{11.47} & \multirow{2}{*}{39.2} \\
\hline & St. Petersburg & 39860 & & \\
\hline \multirow{2}{*}{ South District } & Republic of Kalmykia & 2083 & \multirow{2}{*}{14.46} & \multirow{2}{*}{38.0} \\
\hline & Krasnodar territory & 30118 & & \\
\hline \multirow[b]{2}{*}{ Volga District } & Republic of Marii-El & 2858 & \multirow[b]{2}{*}{14.32} & \multirow[b]{2}{*}{39.9} \\
\hline & $\begin{array}{l}\text { Republic of } \\
\text { Bashkortostan }\end{array}$ & 40927 & & \\
\hline \multirow{2}{*}{ Ural District } & Kurgan region & 3406 & \multirow{2}{*}{16.79} & \multirow{2}{*}{42.3} \\
\hline & Tyumen region & 57174 & & \\
\hline \multirow{2}{*}{$\begin{array}{l}\text { Siberian } \\
\text { District }\end{array}$} & Republic of Tyva & 2692 & \multirow{2}{*}{14.83} & \multirow{2}{*}{39.8} \\
\hline & Kemerovo region & 39928 & & \\
\hline \multirow{2}{*}{$\begin{array}{l}\text { Far-Eastern } \\
\text { District }\end{array}$} & $\begin{array}{l}\text { Jewish Autonomous } \\
\text { district }\end{array}$ & 3074 & \multirow[t]{2}{*}{12.6} & \multirow[t]{2}{*}{37.7} \\
\hline & Sakhalin region & 38848 & & \\
\hline \multirow{2}{*}{$\begin{array}{l}\text { Russian } \\
\text { Federation }\end{array}$} & Republic of Kalmykia & 2083 & \multirow{2}{*}{33.6} & \multirow{2}{*}{42.1} \\
\hline & Moscow city & 69900 & & \\
\hline
\end{tabular}

In 2008 regions the maximum average per capita income (Moscow city - 69900 roubles) in Russian exceeded the minimum average per capita income (the Republic of Kalmykia - 2083 rubles) 33,6 times. The indices of the inequality level of average per capita monetary incomes in the constituent territories of Russia in 2008 are showed in Table 2.

In 2008 the Gini coefficient decreased 0.1 0.2 percentage points in all the federal districts. The exceptions were the Volga district, where the Gini coefficient did not change, and the Southern district, where the Gini coefficient increased 0.2 p.p.

Russian official statistics determine poor population according to the absolute concept of poverty, which states that people with an income lower than the established living wage (LW) in a given region live below the poverty line. Analyzing distribution of the population of the Russian Federation by the average per capita monetary incomes and officially determined LW with the use of the modified Pen's model in 2008 19.675\% (27.68 million people) were below the poverty line. Incomes of $40 \%$ of the population almost did not exceed the LW. The indices essentially differ from the official published figures. According to the Rosstat, 18.5 million people (13.1\% of the Russian population) were poor in 2008. The analysis of the poverty level in Russia in 2000 and 2008 showed that the share of the poor population over the Russian Federation deceased by 5.996 p.p. and 9.67 million people. The most significant reduction of poverty in terms of the relative and absolute indices took place in the Southern district - 4.31 p.p. and 3.12 million people, in the Siberian district - 9.05 p.p. and 2.018 million people. At the third place in terms of the relative indices is the Far-Eastern district 8.97 p.p., and in terms of the absolute indices is the Volga district -1.761 million people. The least change of poverty was in the Ural district (2.05 p.p. or 0.288 million people) that is the lowest indices of poverty in the analyzed period.

Thus, at the present stage of the development of Russia the state policy aimed at regulation of the population income is engaged in the sphere of poverty reduction [1].

Decomposition analysis of change of the poverty level in Russia for 2000-2008 was carried out. The authors used the Ravallion-Huppy method and took into consideration the PPPR for seven federal districts. Change in the poverty level was resolved into three effects: an effect of poverty change within the districts, an effect of change of district share in the population size and an interaction effect. The decomposition analysis showed reduction of the 
poverty level (5.996 p.p.) in Russia in the analyzed period; the effects of change of poverty within the districts have considerable influence on reduction of poverty in the country and are equal to 5.992 p.p. The poverty level with taking into consideration the basic population size in the analyzed period decreased in all federal districts, especially in the Southern, Siberian and Volga districts. The effect of change of the share of districts in the total population size is negligible, and it amounts to 0.03 p.p. However, in the Central, Southern and Ural districts the effect is positive, in the rest - negative. The interaction effects as the results of correlation between changes in poverty level in the districts and population shifts do not play an important part in reduction of the poverty level in the country as a whole $(-0.034$ p.p.).

The progressive taxation scale is an important instrument for the state policy to reduce income inequality. In Russia, as is well-known, the personal income tax (PIT - 13\%) has existed since 1.01.2001. Despite numerous recommendations regarding change of the income tax scale, the government considers that the PIT is appropriate in general and it does not require any serious adjustment [7, p. 85]. Nevertheless, we have investigated possibilities of introducing such a scale in Russia for redistributive overcoming the poverty using the next approach.

The country's population was divided into two parts. For this purpose 410 groups (5 quintile groups of 82 regions without the Chechen Republic) were ranged in the order of increase in average per capita monetary income. Then the aggregate income and aggregate LW were cumulatively calculated in the percentage ratio to the aggregate income of the population. People with the aggregate income below the aggregate LW were referred to the first part of the population. No redistribution of income inside the mentioned group referred by us to as the needy population, allows overcoming the poverty. The rest individuals were referred to the second part of the population, named wealthy people. Redistributive overcoming of poverty is possible only at the expense of redistribution of monetary incomes of wealthy citizens in favor of the poor. Then the size and incomes of each group were calculated.

Figure 2 shows the Lorenz curve and the aggregate LW curve made according to the results of the calculation for 410 groups of the population of the Russian Federation (2008).

The abscissa of the intersection point of these two curves shows the share of the needy population, and the ordinate of this point shows the aggregate LW of the needy population in the percentage ratio to the aggregate income of all the population (the

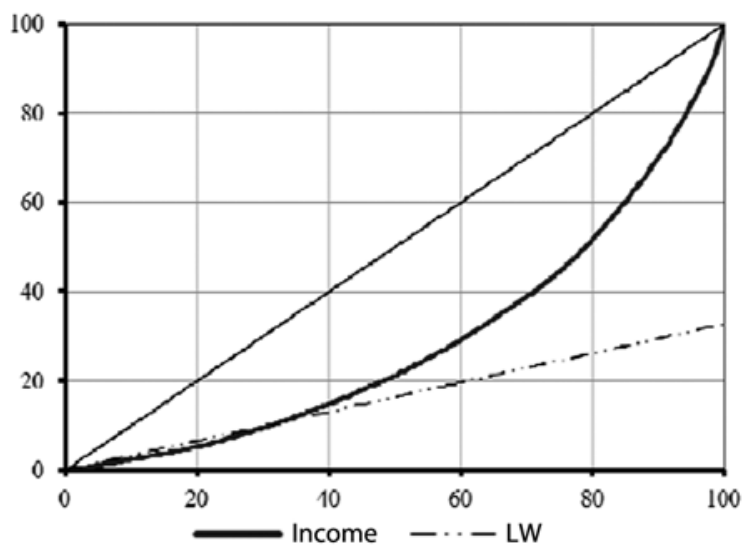

Fig. 2. The Lorenz curve and the aggregate LW according to the population groups of Russian regions in 2008 (Russian average prices of 2008)

cumulative poverty line). If we subtract the share of the aggregate LW of all the population from $100 \%$, we will obtain the top estimate of the amount of incomes that can be redistributed in favor of the poor, not reducing the incomes of citizens below the line of the LW.

The wealthy part of the Russian Federation population amounted to 95.6 million people $(67.9 \%)$. It predominately included the $3^{\text {rd }}, 4^{\text {th }}$, and $5^{\text {th }}$ quintile regional groups, and also five regional representatives of the $2^{\text {nd }}$ group (the Moscow, Tyumen, Kemerovo, Omsk, Chelyabinsk, Sverdlovsk, Sakhalin and Magadan regions, and the Republic of Bashkortostan and Tatarstan).

$32.1 \%$ of the Russian Federation population (45.1 million people without the Chechen Republic), mainly consisting of the $1^{\text {st }}$ and $2^{\text {nd }}$ regional quintile groups. The representatives of the $3^{\text {rd }}$ group of the six poor regions (the Republic of Ingushetia, Kalmykia, Tyva, Adygea, the Republic of Marii-El, the Ivanovo region) and the $4^{\text {th }}$ quintile group of the Republic of Ingushetia and Kalmykia.

The aggregate monthly monetary income of the wealthy part of population amounted to 1824.9 billion rubles in the average Russian prices of 2008 . Aggregate deficiency of monetary means of the population living below the poverty line came to 27.8 billion rubles. It would be sufficient to increase surtax for the wealthy part of the population by 1.5 percentage points to cover this deficiency. If the representatives of the $3^{\text {rd }}$ quintile all-Russian group were excluded from the structure of the wealthy population, it would be necessary to increase a surtax by 1.9 percentage points for the remaining 56.3 million people; if the representatives of the $4^{\text {th }}$ group were also excluded, it would be necessary to increase a surtax by 2.8 percentage points (for 28.1 


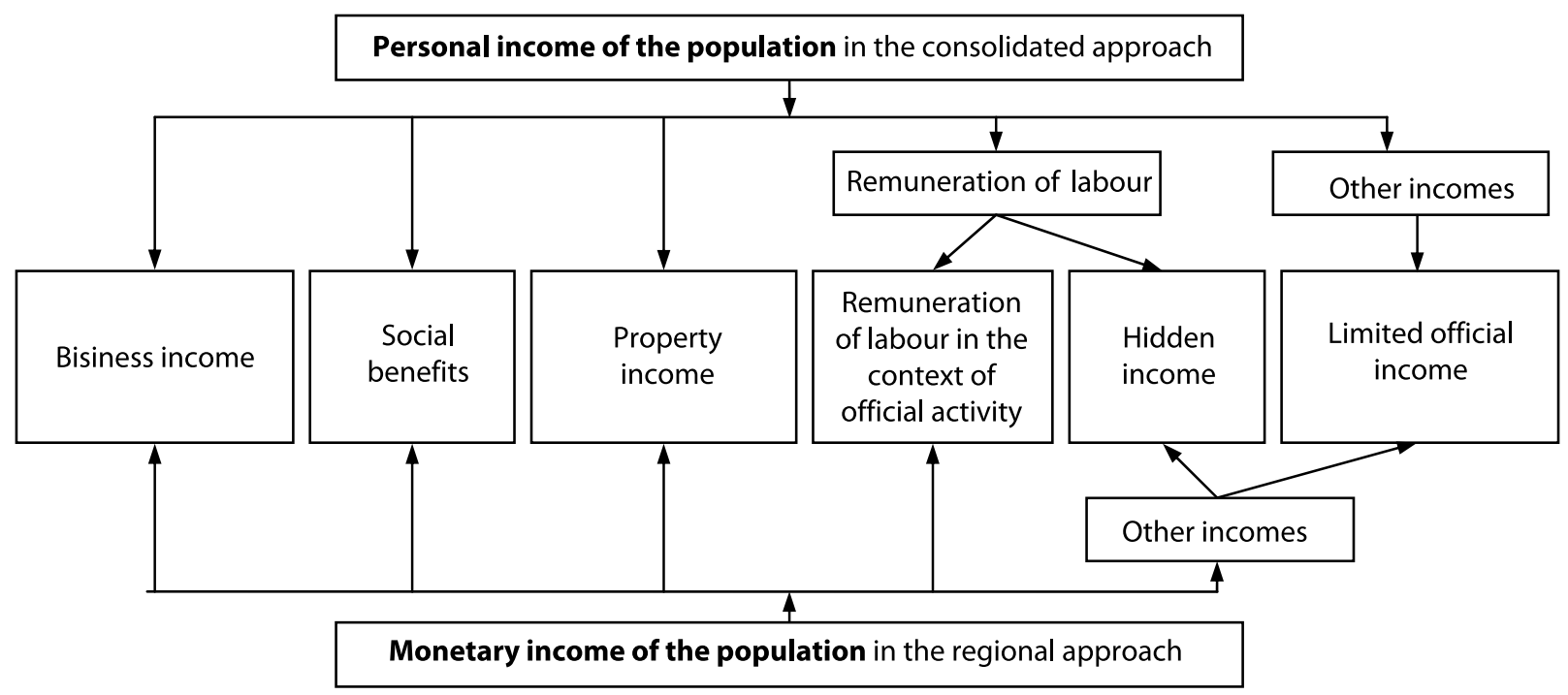

Fig. 3. Structure of monetary incomes in the consolidated and regional approaches, according to the Rosstat

million people from the $5^{\text {th }}$ quintile group). It means increase of the surtax to $15.8 \%$ in comparison to $13.0 \%$ established at present.

However, realizing the social policy apart from the question of introduction a progressive taxation scale, it is necessary to improve the mechanism of social transfers in a way that the transfers are given to the needy, not to the «categories» [7, p. 89].

At the next stage of the research an influence of latent incomes on the inequality and poverty level is analyzed.

Numerous international and domestic studies are devoted to latent, hidden, and unofficial incomes. Economists, lawyers, and statisticians constantly argue about the essence of the categories.

An increased interest to shadow activity is explained by the influence the sector of economy has on the socio-economic processes in regions $[6$, p. 811].

The term «unobserved economy» is used in modern statistics. The following activities are included: underground and illegal production, informal activity, household production for their own final use as well as the kinds of activities omitted due to deficiencies in the basic data collection program. Measurement of unobserved economy in transitive economies has specific features connected with existence of an informal sector, essential volumes of "shuttle trade", wide use of ground for growing food for one's own consumption, and in some countries with substantial scale of illegal activity [2, p. 42, 159].

Development of statistical accounts in the Russian Federation resulted in the fact that monetary incomes of the population published by Rosstat include latent incomes. Latent remuneration of labor and mixed incomes (latent incomes derived from business and informal activity) refer to latent incomes. Incomes from illegal activity do not refer to latent incomes. Latent incomes are determined by a balance method as a difference between aggregate household expenses including increase in financial assets, and formally registered incomes. Calculation of latent incomes is made for the economy as a whole without division into kinds of activities and areas. At the regional level a balancing item is an item "other incomes", which include all types of official incomes of citizens unregistered at a regional level, as well as latent incomes. Thus, the term "other incomes" in the consolidated and regional approach has a different content. Figure 3 shows the structure of monetary incomes in the consolidated and regional approaches.

We think that there is no need to calculate the size of latent incomes at a regional level using a separate algorithm outside the balance of monetary

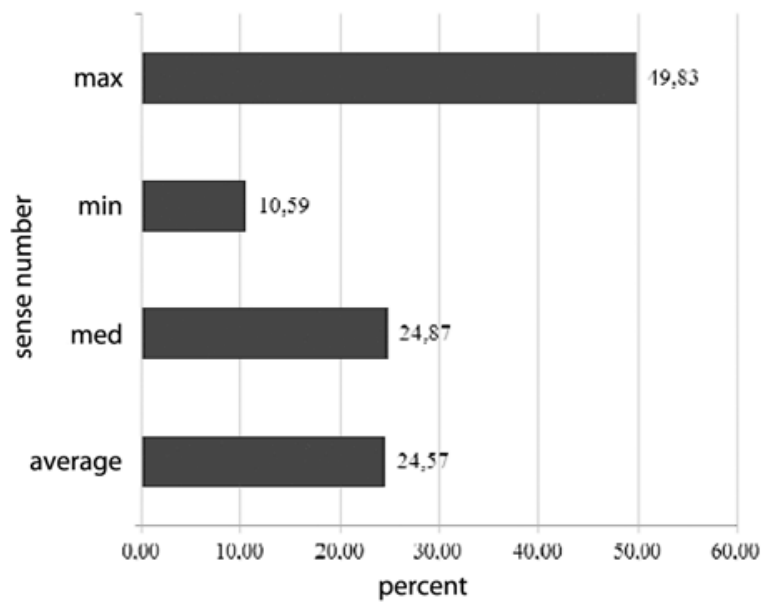

Fig. 4. Values of the share of latent incomes in monetary incomes of the population of the Russian regions (\%) in 2008 
Regions the leaders in terms of the share of official and latent incomes in monetary incomes of population in $2008(\%)$

\begin{tabular}{|l|l|l|l|}
\hline \multicolumn{2}{|c|}{ By official incomes } & \multicolumn{2}{c|}{ By latent incomes } \\
\hline $\begin{array}{l}\text { Nenets autonomous } \\
\text { district }\end{array}$ & 98.71 & Republic of Dagestan & 49.83 \\
\hline $\begin{array}{l}\text { Chukotka } \\
\text { autonomous district }\end{array}$ & 97.88 & $\begin{array}{l}\text { Republic of } \\
\text { Ingushetia }\end{array}$ & 44.58 \\
\hline $\begin{array}{l}\text { Yamal-Nenets } \\
\text { autonomous district }\end{array}$ & 97.05 & Perm territory & 35.27 \\
\hline Magadan region & 96.78 & Rostov region & 35.09 \\
\hline $\begin{array}{l}\text { Khanty-Manssiysk } \\
\text { autonomous district }\end{array}$ & 90.24 & Moscow region & 34.54 \\
\hline Murmansk region & 89.41 & $\begin{array}{l}\text { Republic of } \\
\text { Karachai-Circassian }\end{array}$ & 34.17 \\
\hline Kamchatka territory & 87.38 & $\begin{array}{l}\text { Republic of } \\
\text { Kabardin-Balkar }\end{array}$ & 33.98 \\
\hline $\begin{array}{l}\text { Republic of Sakha } \\
\text { (Yakutia) }\end{array}$ & 87.11 & $\begin{array}{l}\text { Republic of } \\
\text { Bashkortostan }\end{array}$ & 33.89 \\
\hline St. Petersburg & 87.01 & Omsk region & 33.34 \\
\hline Vologodsk region & 86.83 & Tambov region & 33.16 \\
\hline
\end{tabular}

Table 4

Indices of the inequality level of average per capita official monetary incomes in constituent territories in Russia in 2008 (in Russian average 2008 prices)

\begin{tabular}{|c|c|c|c|c|}
\hline $\begin{array}{l}\text { Federal } \\
\text { district }\end{array}$ & \multicolumn{2}{|c|}{$\begin{array}{l}\text { Minimum and } \\
\text { maximum monetary } \\
\text { income, roubles }\end{array}$} & 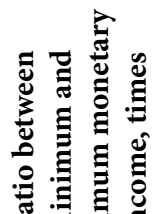 & 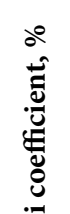 \\
\hline \multirow{2}{*}{$\begin{array}{l}\text { Central } \\
\text { District }\end{array}$} & Voronezh region & 2191 & \multirow{2}{*}{27.3} & \multirow{2}{*}{46.9} \\
\hline & Moscow city & 59857 & & \\
\hline \multirow{2}{*}{$\begin{array}{l}\text { North- } \\
\text { Western } \\
\text { District }\end{array}$} & Pskov region & 2677 & \multirow[b]{2}{*}{13.0} & \multirow[b]{2}{*}{39.7} \\
\hline & St. Petersburg & 34684 & & \\
\hline \multirow{2}{*}{$\begin{array}{l}\text { Southern } \\
\text { District }\end{array}$} & $\begin{array}{l}\text { Republic of } \\
\text { Ingushetia }\end{array}$ & 1174 & \multirow{2}{*}{19.3} & \multirow{2}{*}{38.9} \\
\hline & $\begin{array}{l}\text { Krasnodar } \\
\text { territory }\end{array}$ & 22657 & & \\
\hline \multirow{2}{*}{$\begin{array}{l}\text { Volga } \\
\text { District }\end{array}$} & $\begin{array}{l}\text { Republic of } \\
\text { Marii-El }\end{array}$ & 2337 & \multirow{2}{*}{12.2} & \multirow{2}{*}{39.2} \\
\hline & $\begin{array}{l}\text { Republic of } \\
\text { Tatarstan }\end{array}$ & 28465 & & \\
\hline \multirow{2}{*}{ Ural district } & Kurgan region & 2308 & \multirow{2}{*}{21.4} & \multirow{2}{*}{43.5} \\
\hline & Tyumen region & 49486 & & \\
\hline \multirow{2}{*}{$\begin{array}{l}\text { Siberian } \\
\text { District }\end{array}$} & Republic of Tyva & 2188 & \multirow[b]{2}{*}{12.7} & \multirow[b]{2}{*}{39.5} \\
\hline & $\begin{array}{l}\text { Krasnoyarsk } \\
\text { territory }\end{array}$ & 27830 & & \\
\hline \multirow[t]{2}{*}{$\begin{array}{l}\text { Far-Eastern } \\
\text { District }\end{array}$} & $\begin{array}{l}\text { Jewish } \\
\text { autonomous } \\
\text { district }\end{array}$ & 2485 & \multirow[t]{2}{*}{12.8} & \multirow[t]{2}{*}{38.0} \\
\hline & Magadan region & 31817 & & \\
\hline \multirow{2}{*}{$\begin{array}{l}\text { Russian } \\
\text { Federation }\end{array}$} & $\begin{array}{l}\text { Republic of } \\
\text { Ingushetia }\end{array}$ & 1174 & \multirow[t]{2}{*}{51.0} & \multirow[t]{2}{*}{42.9} \\
\hline & Moscow city & 59857 & & \\
\hline
\end{tabular}

incomes and expenditures of the population because the given item should be balancing at a regional level as well as in Russia as a whole. In order to reveal such unaccounted official incomes at a regional level, the Rosstat should divide «other incomes» into two items: other official incomes; and latent incomes [3].

Under the conditions latent population's incomes of each region ensued as a percentage part of other incomes calculated for country as a whole. At the level of the Russian Federation the share of latent incomes in other incomes of the population are quite stable and equal to $91.8-92.9 \%$.

Official incomes of each region are calculated as the subtraction of the sum of all monetary incomes of population and latent incomes. Figure 4 shows the statistical values of the share of latent incomes in monetary incomes of the population of the Russian regions in 2008.

Table 3 shows the leaders in the share of official and latent incomes. The share of latent incomes exceeded the analogous index calculated over Russia as a whole (23.67\%), in the South, Volga and Siberian districts. The share was lower than the allRussian index in the Ural, Central, Far-Eastern and North-Western districts, the lowest share (15.75\%) was in the North-Western district, the highest (30.48\%) - in the Southern district.

At the fourth stage of the calculation, distribution of official incomes among the quintile groups of the population according to their shares in the total monetary incomes and estimate of influence of latent incomes on the inequality of total incomes of population within federal districts and over the Russia as a whole takes place. The calculation shows that the estimates of an inequality level (the ratio between the maximum average per capita regional income and the minimum average per capita regional income and Gini coefficient) according to the official incomes (Table 4) in comparison to the estimates of total incomes (Table 2) are decreased in the Volga and Siberian federal districts. This shows

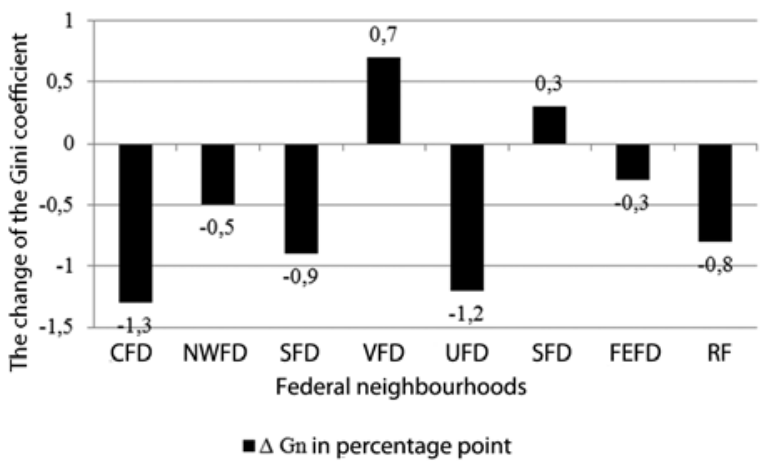

Fig. 5. Influence of latent incomes on the change of the Gini coefficient for the FD in 200, \% 
that latent incomes increase in the inequality level in the districts. Inverse negative relationship exists in the Central, North-Western, South, Ural and FarEastern federal districts: latent incomes decrease the inequality level because the estimates of the level according to the official incomes are deeper than on total incomes.

As a whole, the influence of latent incomes on the level of inequality of monetary incomes of the population in various districts and regions can be different and even opposite. This depends on an income size as well as a structure of distribution in a population group. Figure 5 shows the change of the Gini coefficient $(\Delta G n)$ in federal districts. However, the latent incomes decrease the level of income differentiation of the population over Russia.

Estimates of contribution of latent incomes to the poverty level of people of Russian regions in 2008 were carried out with the use of a modified Pen's model. The calculations showed that latent incomes contribute greatly to reduction of the poverty level in the Far-Eastern, Southern and Volga districts (Table 5). The percentage of the poor population in the districts due to latent incomes decreased 14.92,
11.74 and 9.27 p.p. accordingly. Such a situation lifted up the incomes of 6.3 million people above the poverty level in the districts. In the North-Western federal districts latent incomes do not contribute to poverty of the population. In Russia as a whole due to latent incomes the percentage of poor population decreased 6.76 p.p., and the poor population decreased by 9.51 million people. It is possible to say that latent incomes are the base of the existence at the level of the LW by 9.51 million people.

The calculations on the modified Lorenz's model showed that latent incomes contribute more considerably to the wealth level of Russian people. Due to the incomes the population of wealthy people increased 29.13 million people or 20.71 p.p. in 2008. 6.9 and 7.15 million such citizens lived in the Central and Volga federal districts accordingly, 6.12 million people - in the South district (table 6).

Thus, latent incomes have a positive impact on reduction of level of income differentiation and povertyaswellasincrease in wealthof Russiancitizens. Latent incomes formed in shadow economy at the time of the crisis of socio-economic environment are able to perform not only a destructive function

Table 5

Estimate of contribution of latent incomes to the poverty level of the population of Russian regions in 2008 in federal districts (in Russian average 2008 prices)

\begin{tabular}{|c|c|c|c|c|c|c|}
\hline \multirow{3}{*}{ Federal district } & \multicolumn{4}{|c|}{ Poor population } & \multirow{2}{*}{\multicolumn{2}{|c|}{$\begin{array}{l}\text { Contribution of latent incomes } \\
\qquad(1-2)\end{array}$}} \\
\hline & \multicolumn{2}{|c|}{ on total incomes (1) } & \multicolumn{2}{|c|}{ on official incomes (2) } & & \\
\hline & $\%$ & million people & $\%$ & million people & p.p. & million people \\
\hline Central District & 20.00 & 7.43 & 23.66 & 8.79 & -3.66 & -1.36 \\
\hline North-Western District & 20.00 & 2.70 & 20.00 & 2.70 & 0.00 & 0.00 \\
\hline Southern District & 20.73 & 4.49 & 32.47 & 7.03 & -11.74 & -2.54 \\
\hline Volga District & 20.00 & 6.04 & 29.27 & 8.84 & -9.27 & -2.80 \\
\hline Ural District & 14.47 & 1.77 & 16.03 & 1.96 & -1.56 & -0.19 \\
\hline Siberian District & 20.32 & 3.97 & 28.82 & 5.64 & -8.50 & -1.66 \\
\hline Far-Eastern District & 20.00 & 1.28 & 34.92 & 2.24 & -14.92 & -0.96 \\
\hline Russian Federation & 19.68 & 27.68 & 26.44 & 37.19 & -6.76 & -9.51 \\
\hline
\end{tabular}

Table 6

Estimate of contribution of latent incomes to the wealth level of population in Russian regions in 2008 in federal districts (in Russian average 2008 prices)

\begin{tabular}{|l|c|c|c|c|c|c|}
\hline \multirow{2}{*}{ Federal district } & \multicolumn{4}{|c|}{ Wealthy population } & Contribution of latent incomes \\
& \cline { 2 - 7 } & on total incomes (1) & on official incomes (2) & \multicolumn{2}{c|}{} \\
\cline { 2 - 7 } & \% & million people & \% & million people & p.p. & million people \\
\hline Central District & 71.28 & 26.47 & 52.71 & 19.57 & 18.57 & 6.90 \\
\hline North-Western District & 71.14 & 9.59 & 57.84 & 7.80 & 13.30 & 1.79 \\
\hline Southern District & 64.64 & 13.99 & 36.36 & 7.87 & 28.29 & 6.12 \\
\hline Volga District & 68.54 & 20.70 & 44.88 & 13.55 & 23.66 & 7.15 \\
\hline Ural District & 78.20 & 9.58 & 62.82 & 7.69 & 15.38 & 1.88 \\
\hline Siberian District & 64.11 & 12.53 & 42.04 & 8.22 & 22.07 & 4.32 \\
\hline Far-Eastern District & 58.43 & 3.75 & 41.23 & 2.65 & 17.20 & 1.10 \\
\hline Russian Federation & 67.9 & 95.57 & 47.23 & 66.44 & 20.71 & 29.13 \\
\hline
\end{tabular}


but also a compensating function and to be a shorkabsorber in socio-economic upheavals [6, p. 794]. However, concealment of economic activity causes the redistribution of incomes and property by the deformation of tax policy and relations [6, p. 812].

\section{Conclusions}

1. When analyzing income levels of the population, it is necessary to commensurate the monetary incomes by the ruble purchasing power parity. For the purpose of the right distribution of the Russian population according to their income level it is necessary to distinguish regional quintile population groups and all-Russian quintile groups. The modified Pen's model is an efficient instrument for estimation of population of poor people. The modified Lorenz's model allows investigating the possibilities of the redistributive overcoming of poverty.

2. Analysis of monetary incomes and poverty level of population showed that the differentiation and poverty with the regard to the PPPR in the Russian Federation is quite different from the estimates published by Rosstat. In 2007 according to our calculations the inequality level amounted to $43,3 \%$, according to Rosstat $-42,3 \%$, in 2008 according to our calculations - 42,1\%, according to Rosstat - 42,2 \%. In 2008 in Russian regions the maximum average per capita income (Moscow city - 69900 rubles) exceeded the minimum average per capita income (the Republic of Kalmykia 2083 rubles) 33,6 times. During the whole period of reforms for the exception of 2006 and 2008 the depth of inequality in Russia is not decreasing but increasing.

3. The poverty level of the Russian population calculated on the monetary incomes in 2008 prices in 2007 was equal to $19.924 \%$ (28.07 million people), the wealth level $-65.2 \%$ (91.9 million people). 34.8 $\%$ of Russian citizens (49 million people without the Chechen Republic) were the needy people. In 2008 according to our estimates the poverty level in the Russian Federation decreased 0.25 p.p. and amounted to $19.675 \%$ (27.68 million people). The level of wealthy people increased to $67.9 \%$ (95.6 million people), and the level of needy people decreased to $32.1 \%$ (45.1 million people).

4. The calculations on the regional data show higher in comparison with official statistics meanings of poverty level. The highest shares of people with the incomes below LW in 2000 were in South, Siberian and Far-Eastern districts. In 2008 the share of poor population in federal districts differed slightly and was at the level of $20 \%$. The Ural district was distinguished by the smallest share of poor population
$-14.47 \%$. The share and population of poor people over Russia as a whole decreased 5.996 p.p. (9.67 million people) for 2000-2008. Decomposition analysis showed that effects of changes of poverty level inside districts have dominating influence on the decrease in poverty level in country. The effects of change of the share of districts in total population and the effects of interactions resulting from the correlation between the changes in poverty level in districts and population shifts are negligable.

5. It would be sufficient to increase in 2008 a surtax for 28.1 million most wealthy citizens by 2.8 p.p., i.e. to increase it to $15.8 \%$ in comparison with $13.0 \%$ established now to overcome poverty in Russia by the redistributive way. Realizing the social policy aside from the question of introducing an ascending tax scale it is necessary to improve the mechanism of social transfers so that the transfers are given to the needy not to the «categories».

6. Latent incomes have positive influence on the reduction of the level of income differentiation and poverty as well as on the increase in wealth of people. At the level of the Russian Federation the share of latent incomes in other incomes of population is stable and amounts to $91.8-92.9 \%$. In 2008 in the Russian Federation the ratio between maximum income and minimum income according to official income data (51 times) was essentially higher than according to monetary incomes including latent incomes (33.6 times), i.e. over Russia as a whole latent incomes decrease income differentiation of population. However, it should be noted that influence of latent incomes on the inequality level of monetary incomes of population is different and even opposite in various districts and constituent territories. Latent incomes provide the way of living at the level of LW for 9.51 million people. The calculations on the modified Lorenz's model showed that latent incomes contribute more considerably to the wealth level of Russian people. Due to the incomes the population of wealthy people increased 29.13 million people or 20.71 p.p. If we didn't take into consideration latent incomes, monetary incomes of population would be lower and poverty level - higher in all regions in Russia. Rosstat should solve the problem of estimates of latent incomes at regional level and divide «other incomes» into two entries: other official incomes; and latent incomes. Moreover, it is necessary to unify the index «latent incomes» in all statistical collections of the Russian Federation.

7. The police of regulation of population incomes is carried out only in the sphere of poverty reduction. Active policy on reduction of income differentiation is 
not carried out, the instruments for achieving the goal are not in use. The withdrawal of state from the sphere of regulation of income differentiation of population brings to negative consequences for society.

\section{References}

1. Voronkova, O. V. (2009). State Policy of regulation of poverty level of population in Russia and other countries. Terra economicus. V. 7. № 2. pp. 74-81.

2. Measurement of Non-Observed Economy: guide. Paris, 2002. Retrieved from: http://www.unece.org/stats/ documents/2007/04/noe/zip.30.r.pdf .

3. Litvintseva, G. P. (2008). Monetary incomes of population in the Russian regions with regard to the purchasing power of ruble and latent incomes. Voprosy Statistiki, 6. pp. 29-38.

4. Litvintseva, G. P., Voronkova, O. V., Stukalenko, E. A. (2009). Regional income differentiation of the Russian population with the regard to the purchasing power of ruble. Vestnik INGEKONa, 7. pp. 84-95.
5. Litvintseva, G. P., Voronkova, O. V., Stukalenko, E. A. (2007). Regional income inequality and poverty level of the Russia: an analysis adjusted for the purchasing power of ruble. Problemy prognozirovania, 6. pp. 119-131.

6. Socio-economic risks: diagnostics of reasons and predictive scripts of neutralization. Ed. by Chereshnev V. A., Tatarkin A. I. Ekaterinburg: Institute of Economics, the Ural Branch of Russian Academy of Sciences, 2010. 1200 p.

7. Stukalenko, E. A. (2009). State regulation of population's income. Quality of life of population in Russia and its regions: collective research. Ed. by Kuschenko S. V., Litvintseva G. P., Osmuk L. A. Novosibirsk: NSTU Publishing, pp. 71-94.

\section{UDC 330.564.2+338.242.4}

keywords: income inequality of the population, official incomes, latent incomes, ruble purchasing power, quintile groups, modified models of Pen, Lorenz, Ravallion-Huppi approach, inter-regional differentiation of monetary incomes, Russian regions, state policy of decrease in inequality of incomes of the population 